\author{
O.I. Oranska, Yu.I. Gornikov, A.V. Brichka, S.Ya. Brichka
}

\title{
THERMAL ANALYSIS, PHASE AND MORPHOLOGICAL TRANSFORMATIONS IN THE COMPOSITES ALUMINOSILICATE NANOTUBES/ACETATES OF Ni, $\mathrm{Cu}, \mathrm{Zn}$
}

\author{
Chuiko Institute of Surface Chemistry of National Academy of Sciences of Ukraine \\ 17 General Naumov Str., Kyiv, 03164, Ukraine, E-mail: el_oranska@mail.ru
}

The thermal stability and solid-phase reactions in composites halloysite nanotubes - acetates of $\mathrm{Ni}, \mathrm{Cu}, \mathrm{Zn}$ in the temperature range from 20 to $1100{ }^{\circ} \mathrm{C}$ have been investigated. It has been shown that chemical reactions occur with metal oxides formed due to thermal degradation of acetates and components of aluminosilicate matrix formed during dehydration and dehydroxylation of halloysite nanotubes. Reaction products are nanocrystalline $\mathrm{ZnAl}_{2} \mathrm{O}_{4}$ distributed in a matrix of amorphous $\mathrm{SiO}_{2}$ and $\mathrm{CuO}$ solid solution in $\alpha$-cristobalite. Degree of destruction of the tubular structure of nanotubes in the composites with acetate increases as follows: $\mathrm{Ni}^{2+}<\mathrm{Zn}^{2+}<\mathrm{Cu}^{2+}$.

Keywords: halloysite nanotubes, oxides $\mathrm{NiO}, \mathrm{CuO}, \mathrm{ZnO}$, nanocrystalline $\mathrm{ZnAl}_{2} \mathrm{O}_{4}$, solid-phase reactions, tubular structure

\section{INTRODUCTION}

Currently, not only natural aluminosilicate (halloysite) nanotubes (HNT), but HNTcomposites are used in various fields of medicine, industry, and agriculture. In general, composites are produced by modifying the outer surface of the nanotubes by impregnating the organic and inorganic substances in the inner cavities of the nanotubes, as well as by introduction of HNT into the mixture as component [1-3]. When using composites based on HNT and metal-containing components as catalysts or their substrates, for the manufacture of ceramic and construction materials and special purpose coatings, knowledge of their physico-chemical properties over a wide temperature range is important. Mechanical mixing of the components in the solid state is one of the most effective and available methods for producing composites with HNT. Study on thermal stability and solid-state reactions that occur in such systems with increasing temperature is of great scientific and practical interest.

In this work, the interaction between the acetates of transition metals and aluminosilicate halloysite nanotubes (HNT) with formula $\mathrm{Al}_{2}\left[\mathrm{Si}_{2} \mathrm{O}_{5}\right](\mathrm{OH})_{4} \cdot \mathrm{nH}_{2} \mathrm{O}$ during heating up to $1000{ }^{\circ} \mathrm{C}$ has been studied. Materials and knowledge of their thermal properties are important for creation and exploitation of heterogeneous catalysts [4]. Previously, it was shown that the chemical reactions in the composites $\mathrm{HNT} / \mathrm{NiO}, \mathrm{CuO}, \mathrm{ZnO}$ proceeded after destruction of the hexagonal structure of nanotubes at the temperatures above $600{ }^{\circ} \mathrm{C}$ [5]. This study will enhance the understanding of the mechanism of interaction between the components of the composites.

\section{MATERIALS AND METHODS}

The test samples were composites of halloysite nanotubes "ND Life" and metal acetate reagents: $\mathrm{Ni}\left(\mathrm{CH}_{3} \mathrm{COO}\right)_{2} \cdot 4 \mathrm{H}_{2} \mathrm{O}$ (NiAc) TU 6-09-3848-87, $\mathrm{Cu}\left(\mathrm{CH}_{3} \mathrm{COO}\right)_{2} \cdot \mathrm{H}_{2} \mathrm{O}$ (CuAc) GOST 5852-79, $\mathrm{Zn}\left(\mathrm{CH}_{3} \mathrm{COO}\right)_{2} \cdot 2 \mathrm{H}_{2} \mathrm{O}(\mathrm{ZnAc}) \mathrm{GOST} 5823-78$. The content of metal acetate in the mixture was $1 \mathrm{mmol} / \mathrm{g}$ HNT. Composites were prepared by mechanica mixing the components.

Thermal analysis was performed using a Q-1500D (MOM firm, Hungary) derivatograph in the temperature range of $20-1000^{\circ} \mathrm{C}$ with linear heating rate of $10 \mathrm{deg} / \mathrm{min}$. Phase composition of the cooled samples was determined by X-ray diffraction using a DRON-4-07 diffractometer with Bragg-Brentano geometry, filtered $\mathrm{Cu} K_{\alpha}$ radiation in the angular range $2 \theta$ of $10-80^{\circ}$. Particle morphology was studied with a scanning electron microscopy instrument MIRA3 LMU, TESCAN with a resolution of $1 \mathrm{~nm}$. The specific surface area 
was measured by low temperature nitrogen desorption.

\section{RESULTS AND DISCUSSION}

It is known that thermal decomposition of aluminosilicate nanotubes occurs in several stages with mass loss corresponding to the removal of the interlayer water at about $100{ }^{\circ} \mathrm{C}$ and intralayer hydroxyls at 500-600 ${ }^{\circ} \mathrm{C}$ [6]. For HNT "ND Life" one more stage of decomposition with weight loss at $310^{\circ} \mathrm{C}$ is characteristic (Fig. $1 \mathrm{a}$ ). According to $\mathrm{X}$-ray diffraction and thermal studies, halloysite nanotubes include an appreciable amount of gibbsite $\mathrm{Al}(\mathrm{OH})_{3} \cdot 3 \mathrm{H}_{2} \mathrm{O}$, as accompanying mineral [7]. This is evidenced by the corresponding diffraction peaks in the diffraction pattern of initial HNT (Fig. 1 b). Heating the sample to about $300{ }^{\circ} \mathrm{C}$ leads to decomposition of gibbsite to form alumina, which corresponds to a mass loss and endoeffect on TG and DTA curves. Heating the sample to $800{ }^{\circ} \mathrm{C}$ leads to crystallization of the alumina in the form of $\gamma-\mathrm{Al}_{2} \mathrm{O}_{3}$ spinel, which is indicated by the appearance of corresponding peaks in the diffractogram of the sample (Fig. $1 b$ ). $\mathrm{Al}_{2} \mathrm{O}_{3}$ crystallization proceeds without visible thermal effect on the DTA curve. When the sample is heated up to $1050{ }^{\circ} \mathrm{C}$, clear exothermic peak at $995^{\circ} \mathrm{C}$ is observed on the DTA curve. X-ray diffraction data indicate the formation of a crystalline phase with a structure similar to $\gamma-\mathrm{Al}_{2} \mathrm{O}_{3}$ in this case. According to [8], this effect is associated with a phase transition in the amorphous aluminosilicate matrix, product of dehydration and dehydroxylation of HNT, leading to the formation of Al-Si spinel with formula $2 \mathrm{Al}_{2} \mathrm{O}_{3} \cdot 3 \mathrm{SiO}_{2}$.

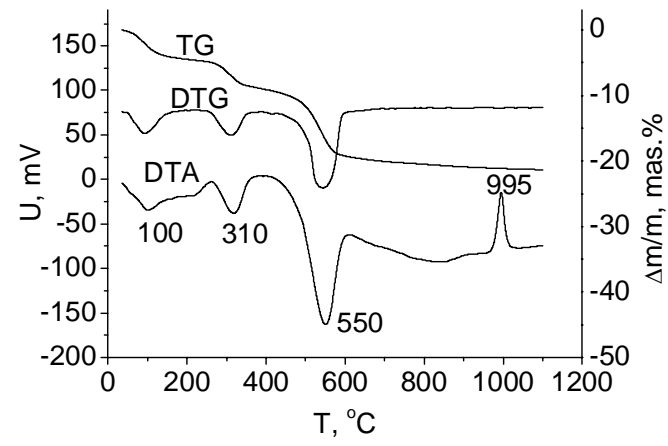

$a$

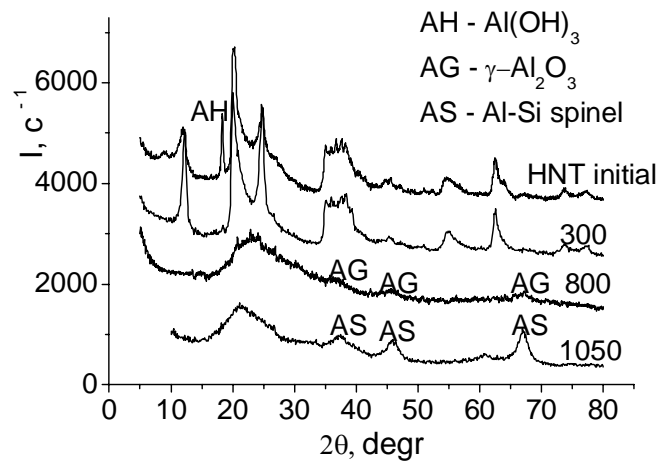

$b$

Fig. 1. Thermal curves of HNT $(a)$, XRD patterns of initial and HNT heated at different temperature $(b)$

Derivatograms of hydrated metal acetates are shown in Fig. $2 a-c$. They are characterized by two temperature regions where the mass loss corresponds to the removal of adsorbed water at $100-150{ }^{\circ} \mathrm{C}$ and removal of the destruction products of acetates at $250-430{ }^{\circ} \mathrm{C}$. Among the acetates, $\mathrm{CuAc}$ has the highest temperature removal of hydrate water $145-150{ }^{\circ} \mathrm{C}$ and the lowest acetate decomposition temperature 280$293{ }^{\circ} \mathrm{C}$. Oxides $\mathrm{ZnO}, \mathrm{CuO}$, and $\mathrm{NiO}$ are products of decomposition of metal acetates and they are formed at the temperatures lower than that of HNT decomposition.

Derivatograms of mixtures of metal acetates and HNT are presented in Fig. $2 d-f$. Observed changes of mass and thermal effects on TG and DTA curves correspond to successive processes, such as removal of adsorbed water, interlayer water in the HNT, removal of acetate of hydration water, hydroxyls of gibbsite, decomposition products of acetate, intralayer hydroxyls of HNT, formation of $\mathrm{NiO}, \mathrm{CuO}$, and $\mathrm{ZnO}$ and exothermic process at $925^{\circ} \mathrm{C}$ for mixture ZnAc-HNT. On DTG curves of mixtures, a shift of the acetate destruction temperatures to lower values is observed. Probably, this is related to superposition of the dehydration process of gibbsite in the same temperature range.

XRD data of the mixtures cooled after heating in furnace of derivatograph up to $1000{ }^{\circ} \mathrm{C}$ indicate a series of phase transformations (Fig. 3). There are amorphous silica, Al-Si spinel, and $\mathrm{NiO}$ in $\mathrm{NiAc}-$ HNT mixture. Thus, on DTA curve of the sample exoeffect at about $1000{ }^{\circ} \mathrm{C}$ observed for initial $\mathrm{HNT}$ is registered. In the sample $\mathrm{CuAc-HNT}$ amorphous silica, $\alpha$-cristobalite and mullite are detected. The latter is usually formed in 
aluminosilicates at higher temperatures $\left(\sim 1200{ }^{\circ} \mathrm{C}\right)$. Crystalline $\mathrm{CuO}$ is not found since, apparently, it forms a solid solution in $\alpha$-cristobalite, as shifts of diffraction peaks of $\mathrm{SiO}_{2}$ are indicated [9]. It is known from the literature that the temperature of mullite formation in the presence of $\mathrm{CuO}$ reduces to values closed to the decomposition temperature of the copper oxide,

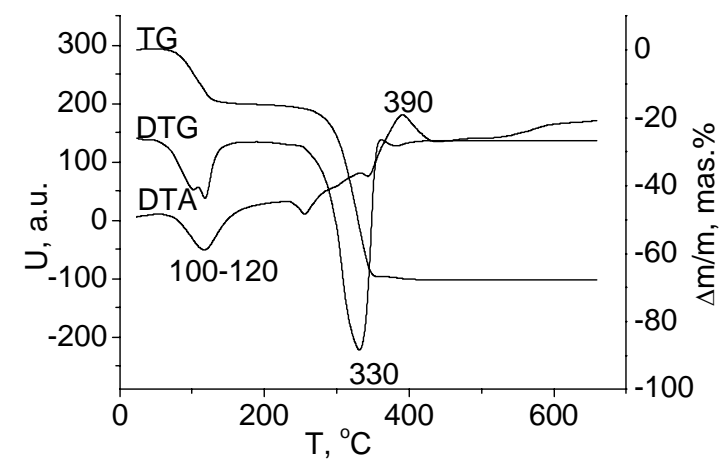

$a$

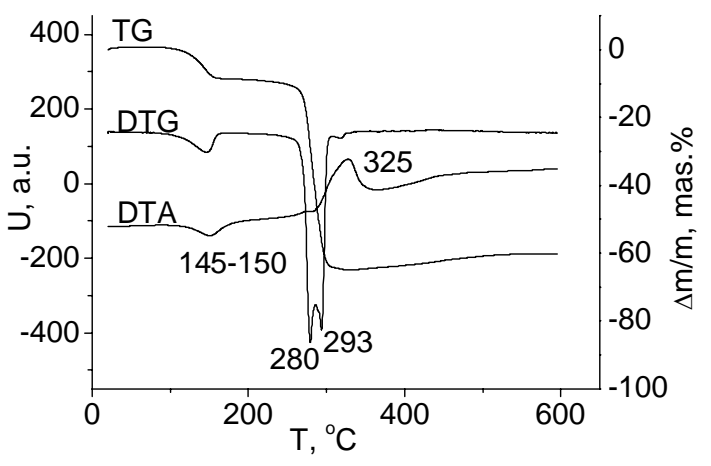

$b$

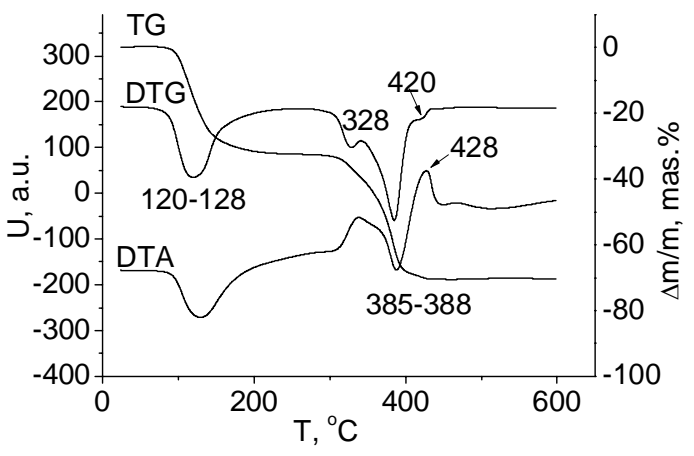

$c$ $\sim 1030{ }^{\circ} \mathrm{C}[10,11]$. ZnAc-HNT mixture, unlike other mixtures heated to $1000{ }^{\circ} \mathrm{C}$, contains zinc aluminate $\mathrm{ZnAl}_{2} \mathrm{O}_{4}$ with spinel type structure and amorphous silica. As noted earlier, there is a narrow exothermic peak at $925^{\circ} \mathrm{C}$ on DTA curve of this sample, similar to that recorded for the initial HNT at $995^{\circ} \mathrm{C}$.

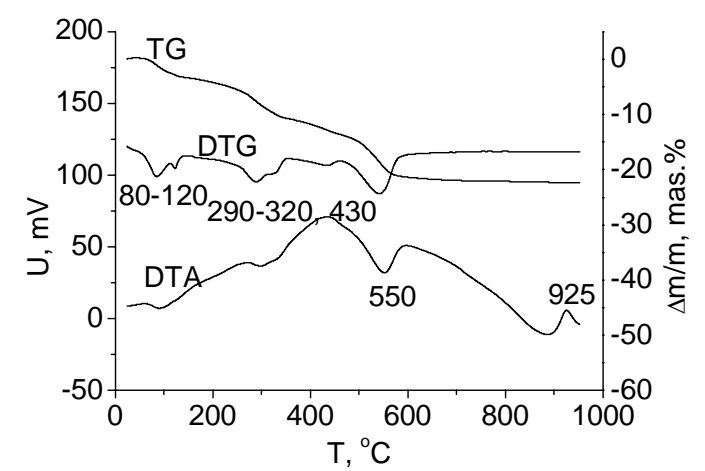

$d$
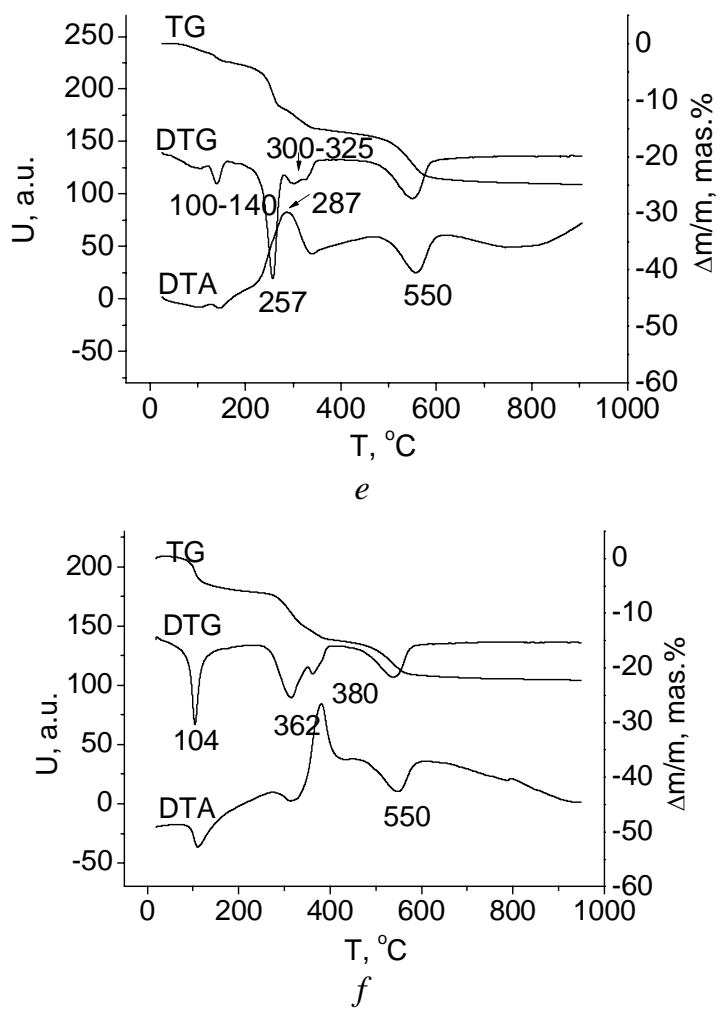

Fig. 2. Thermal curves of ZnAc (a), CuAc (b), NiAc (c), ZnAc-HNT (d), CuAc-HNT (e), NiAc-HNT $(f)$

The formation of zinc aluminate can be explained from the viewpoint of increasing the reactivity of the solids in the solid phase reactions occurring simultaneously with structural transformations in the system - increased reactivity of solid-state during and as a consequence of the transformation of the crystal is known as Hedvall effect [12-15]. Thus, according to XRD of the mixtures, heated to 500 and $600{ }^{\circ} \mathrm{C}$ (Fig. 4), reducing of crystalline $\mathrm{ZnO}$ content with increasing heating temperature (Fig. 4) and the disappearance of diffraction peaks of $\mathrm{ZnO}$, when the heating 
temperature of $800{ }^{\circ} \mathrm{C}$ is observed. At the same time, the content of crystalline $\mathrm{CuO}$ and $\mathrm{NiO}$ in the mixtures CuAc-HNT and NiAc-HNT is not reduced by heating to $600^{\circ} \mathrm{C}$. Consequently mixture ZnAc-HNT becomes amorphous near $800{ }^{\circ} \mathrm{C}$ and at $925^{\circ} \mathrm{C}$ it transforms in to spinel $\mathrm{ZnAl}_{2} \mathrm{O}_{4}$. Based on these data, one can suggest that the interaction between $\mathrm{ZnO}$ and aluminosilicate matrix begins after HNT dehydroxylation and $\mathrm{ZnO}$ dissolves in areas enriched in aluminum, including areas of $\mathrm{Al}_{2} \mathrm{O}_{3}$ formed by the decomposition of gibbsite.

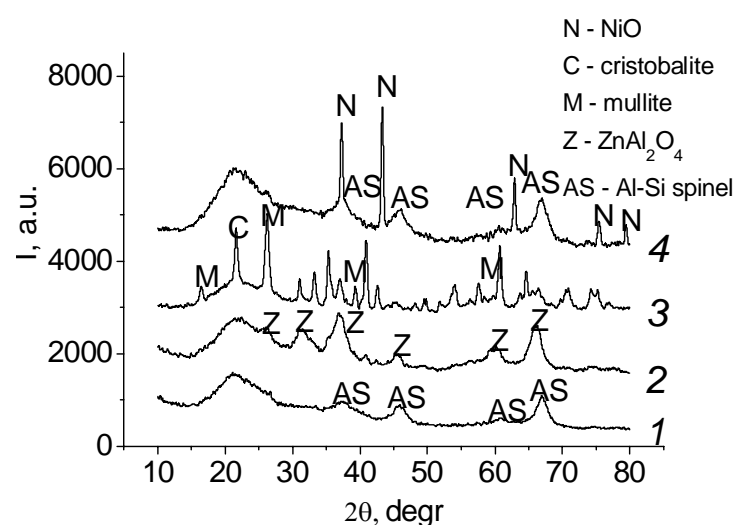

Fig. 3. XRD patterns of HNT (1), ZnAc/HNT (2), $\mathrm{CuAc} / \mathrm{HNT}$ (3), NiAc/HNT (4) heated to $1050^{\circ} \mathrm{C}$

XRD analysis of CuAc-HNT mixture heated from 600 to $1050{ }^{\circ} \mathrm{C}$ shows reduction of crystalline $\mathrm{CuO}$ and formation of $\mathrm{Al}-\mathrm{Si}$ spinel near the decomposition temperature of $\mathrm{CuO} \sim 1030{ }^{\circ} \mathrm{C}$, the formation of mullite and $\mathrm{CuO}$ solid solution in $\alpha$ cristobalite. Therefore for mixture CuAc-HNT the interaction of $\mathrm{CuO}$ and $\mathrm{Al}-\mathrm{Si}-\mathrm{O}$ matrix of dehydroxylated HNT is also characteristic and it occurs mainly in regions enriched with silica, not

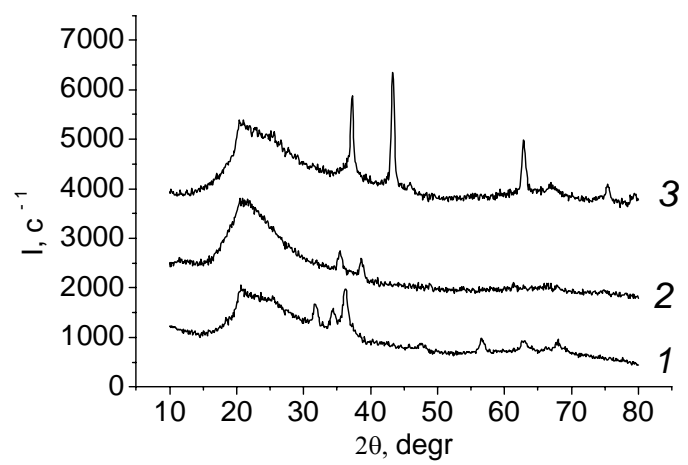

$a$ alumina. Increasing the temperature of heating the mixture NiAc-HNT from 600 to $1000{ }^{\circ} \mathrm{C}$ leads to growth of crystallinity of $\mathrm{NiO}$ and, simultaneously, to formation of $\mathrm{Al}-\mathrm{Si}$ spinel. Therefore, in mixture $\mathrm{NiAc}-\mathrm{HNT}$ no interaction of $\mathrm{NiO}$ with elements of $\mathrm{Al}-\mathrm{Si}-\mathrm{O}$ matrix occurs in this temperature range.

Therefore, the phase composition of the composites of HNT and metal acetates of $\mathrm{Zn}, \mathrm{Cu}$, $\mathrm{Ni}$ depends on the heating temperature and on the reactivity of oxides $\mathrm{ZnO}, \mathrm{CuO}, \mathrm{NiO}$ with respect to the elements of Al-Si-O matrix.

Based on the values of the average crystallite size $6-7 \mathrm{~nm}$ calculated by Scherrer equation, crystalline phase $\mathrm{Al}-\mathrm{Si}$ spinel and $\mathrm{ZnAl}_{2} \mathrm{O}_{4}$ formed at about $1000{ }^{\circ} \mathrm{C}$ can be attributed to nanocrystalline one distributed in the silica matrix.

The specific surface area, $S_{\text {spec, }}$ of the samples, initial and annealed at 320,700 , and $1050^{\circ} \mathrm{C}$ of HNT, ZnAc-HNT, and CuAc-HNT annealed at $1050{ }^{\circ} \mathrm{C}$, is $54,53,80,37,17$, and less than $1 \mathrm{~m}^{2} / \mathrm{g}$, respectively. Based on almost identical values $S_{\text {spec }}$ samples of HNT - initial and annealed at $320^{\circ} \mathrm{C}-$ decomposition temperature of gibbsite, it can be assumed that gibbsite crystals do not form separate particles, but are embedded into the layered structure of HNT. $\mathrm{S}_{\text {spec }}$ of HNT, ZnAc-HNT, and CuAc-HNT annealed at $1050{ }^{\circ} \mathrm{C}$ has a smaller value associated with the destruction of HNT and phase transformations in the samples. A larger value $S_{\text {spec }}$ of $H N T$ annealed at $700{ }^{\circ} \mathrm{C}$, compared to the initial HNT, is apparently due to the increase in the number of defects and voids on the surface of the particles as a result of HNT dehydroxylation at $550{ }^{\circ} \mathrm{C}$.

$\mathrm{S}_{\text {spec }}$ data correlate well with SEM data presented in Fig. 5.

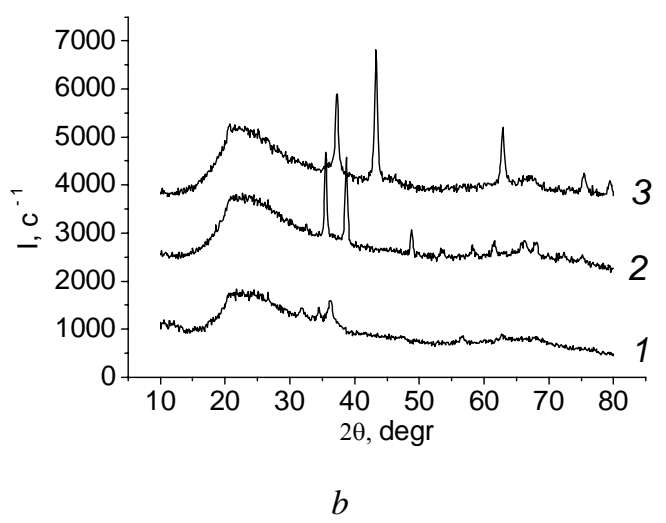

Fig. 4. XRD patterns of ZnAc-HNT (1), CuAc-HNT (2), NiAc-HNT (3) heated to 500 (a) and $600{ }^{\circ} \mathrm{C}(b)$ 


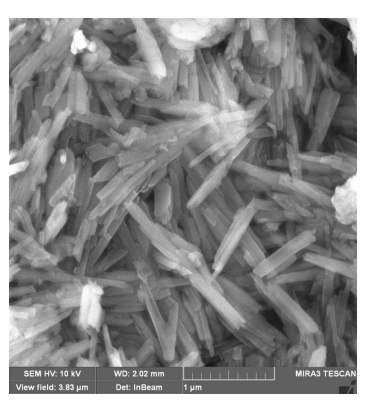

$a$

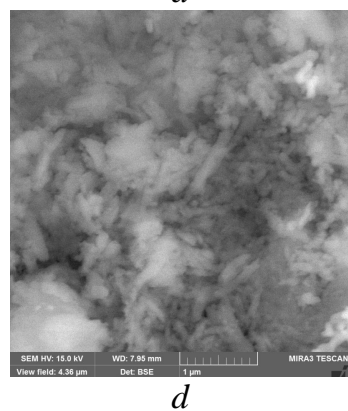

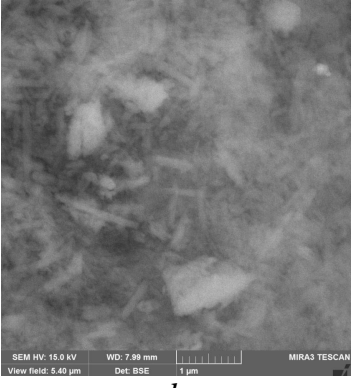

$b$

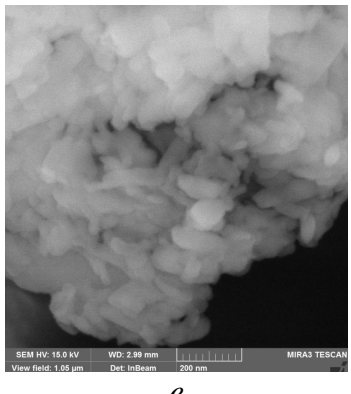

$e$

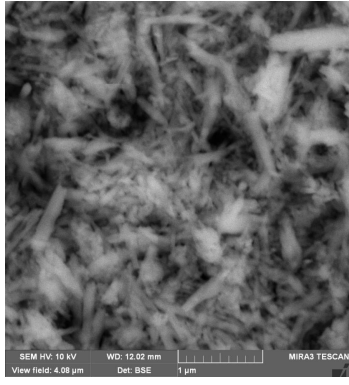

$c$

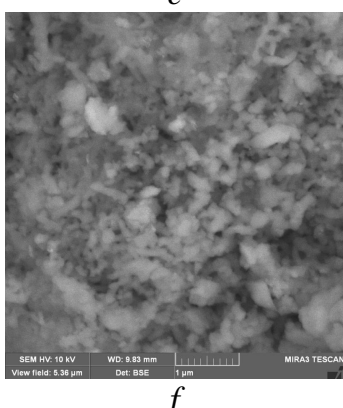

Fig. 5. SEM images: initial (a) and heated to $700{ }^{\circ} \mathrm{C}(b), 1050^{\circ} \mathrm{C}(c) \mathrm{HNT}$, and composites ZnAc-HNT ( $d$, $e$ different magnification) and $\mathrm{CuAc}-\mathrm{HNT}(f)$ heated at $1050^{\circ} \mathrm{C}$

Images in Fig. $5 a-c$ illustrate the morphologic changes of HNT particles heated to 700 and $1050{ }^{\circ} \mathrm{C}$. It is seen that the transformation in aluminosilicate matrix of $\mathrm{HNT}$ at 700 and $1050{ }^{\circ} \mathrm{C}$ leads to partial destruction of the tubular structure of initial HNT. Similar transformations occur in the mixture NiAc-HNT heated up to $1000^{\circ} \mathrm{C}$ (data not shown). In a mixture of ZnAc-HNT heating to $1050{ }^{\circ} \mathrm{C}$ followed by destruction of the tubular structure form ellipsoidal particle with size of 100-200 nm assembled into aggregates of various shapes and lengths (Fig. $5 d-e$ ). The greatest destruction of the tubular structure of HNT occurs in $\mathrm{CuAc}$-HNT mixture heated up to $1050{ }^{\circ} \mathrm{C}$, which is characterized by the formation of two crystalline phases - mullite and $\mathrm{CuO}$ solid solution in $\alpha$-cristobalite (Fig. $5 f$ ).

\section{CONCLUSIONS}

Based on the results of a combined study on composites of HNT and metal acetates under heating to $\sim 1050^{\circ} \mathrm{C}$ using TG, DTG, DTA methods, XRD, SEM, low temperature nitrogen desorption analysis, following findings are made:

1. Presumably gibbsite, part of the HNT mark "ND Life", is not present as a separate phase. Heating of HNT to $1000{ }^{\circ} \mathrm{C}$ is followed by an exothermic phase transition in the $\mathrm{Al}-\mathrm{Si}-\mathrm{O}$ matrix at $995{ }^{\circ} \mathrm{C}$ to form a nanocrystalline $\mathrm{Al}-\mathrm{Si}$ spinel (average crystallite size $6 \mathrm{~nm}$ ) and amorphous $\mathrm{SiO}_{2}$.

2. In the mixtures HNT-metal acetate, the interaction of oxides $\mathrm{NiO}, \mathrm{CuO}, \mathrm{ZnO}$ formed upon decomposition of acetates at $300-400{ }^{\circ} \mathrm{C}$ with HNT aluminosilicate matrix occurs at the temperatures exceeding the destruction temperature of $\operatorname{HNT}\left(550{ }^{\circ} \mathrm{C}\right)$.

3. The result of the interaction of zinc oxide and aluminosilicate matrix is the formation of nanocrystalline zinc aluminate spinel $\mathrm{ZnAl}_{2} \mathrm{O}_{4}$ (the average crystallite size of $7 \mathrm{~nm}$ ) in a matrix of amorphous silica with particles of an ellipsoidal shape and size along the long axis of 100-200 nm, followed by exothermic effect at $925^{\circ} \mathrm{C}$.

4. In the mixture $\mathrm{CuAc}-\mathrm{HNT}, \mathrm{CuO}$ reacts with silica to form a solid solution in $\alpha$-cristobalite. Al-Si spinel is formed at the same time, what happens without exoeffect. With increasing the temperature to the decomposition of $\mathrm{CuO}$ $\sim 1030{ }^{\circ} \mathrm{C}$, Al-Si spinel is converted into mullite accompanied by the complete destruction of the tubular structure of HNT.

5. In the mixture NiAc-HNT, crystallization of $\mathrm{NiO}$ and $\mathrm{Al}-\mathrm{Si}$ spinel occurs independently. Spinel formation takes place without noticeable exothermic effect. High-temperature morphological changes in the mixture are similar to those observed in the initial HNT. 


\title{
Термічний аналіз, фазові та морфологічні перетворення в композитах алюмосилікатні нанотрубки/ацетати $\mathrm{Ni}, \mathrm{Cu}, \mathrm{Zn}$
}

\author{
О.І. Оранська, Ю.І. Горніков, А.В. Бричка, С.Я. Бричка \\ Інститут хімії поверхні ім. О.О. Чуйка Національної академії наук Украӥни \\ вул. Генерала Наумова, 17, Київ, 03164, Україна, el_oranska@mail.ru
}

\begin{abstract}
Досліджена термічна стабільність і твердофазні реакиії в композитах галлуазитні нанотрубки ацетати $\mathrm{Ni}, \mathrm{Cu}, \mathrm{Zn}$ в області температур від 20 до $1100^{\circ} \mathrm{C}$. Показано, щз хімічні реакиї в композитах перебігають за участю оксидів металів, які утворились в результаті термічної деструкиії ацетатів, та елементів алюмосилікатної матриці, яка утворилася при дегідратації $i$ дегідроксилюванні галлуазитних нанотрубок. Продуктами взаємодії є нанокристалічний $\mathrm{ZnAl}_{2} \mathrm{O}_{4}$, розподілений у матричі аморфного $\mathrm{SiO}_{2}$, і твердий розчин $\mathrm{CuO}$ в $\alpha$-кристобаліті. Ступінь руйнування тубулярної структури нанотрубок збільшується в ряду композитів з ащетатом: $\mathrm{Ni}^{2+}<\mathrm{Zn}^{2+}<\mathrm{Cu}^{2+}$.
\end{abstract}

Ключові слова: галлуазитні нанотрубки, оксиди $\mathrm{NiO}, \mathrm{CuO}, \mathrm{ZnO}$, нанокристалічний $\mathrm{ZnAl}_{2} \mathrm{O}_{4}$, твердофазні реакиії, тубулярна структура

\section{Термический анализ, фазовые и морфологические превращения в композитах алюмосиликатные нанотрубки/ацетаты $\mathrm{Ni}, \mathrm{Cu}, \mathrm{Zn}$}

\section{Е.И. Оранская, Ю.И. Горников, А.В. Бричка, С.Я. Бричка}

Институт химии поверхности им. А.А. Чуйко Национальной академии наук Украинь Ул. Генерала Наумова, 17, Киев, 03164, Украина, E-mail: el_oranska@mail.ru

Исследована термическая стабильность и твердофазные реакиии в композитах галлуазитные нанотрубки - ацетаты $\mathrm{Ni}, \mathrm{Cu}, \mathrm{Zn}$ в области температур от 20 до $1100^{\circ} \mathrm{C}$. Показано, что химические реакиии в композитах протекают при участии оксидов металлов, образовавшихся в результате термической деструкции ачетатов, и элементов алюмосиликатной матрицы, образовавщейся при дегидратаиии и дегидроксилировании галлуазитных нанотрубок. Продуктами взаимодействия являются нанокристаллический $\mathrm{ZnAl}_{2} \mathrm{O}_{4}$, распределенный в матрице аморфного $\mathrm{SiO}_{2}$, и твердьй раствор СиО в $а$-кристобалите. Степень разрушения тубулярной структуры нанотрубок увеличивается в ряду композитов с ацетатом: $\mathrm{Ni}^{2+}<\mathrm{Zn}^{2+}<\mathrm{Cu}^{2+}$.

Ключевые слова: галлуазитные нанотрубки, оксиды $\mathrm{NiO}, \mathrm{CuO}, \mathrm{ZnO}$, нанокристаллический $\mathrm{ZnAl}_{2} \mathrm{O}_{4}$,твердофазные реакции, тубулярная структура 


\section{REFERENCES}

1. Joussein E., Petit S., Churchman J. et al. Halloysite clay minerals: a review, Clay minerals, 40 (2005) 383.

2. Brichka S.Ya. Natural aluminosilicate nanotubes: structure and properties, Mater. Sci. Nanostruc., 2 (2009) 40 (in Russian).

3. Brichka S.Ya. Application of aluminosilicate nanotubes, Mater. Sci. Nanostruc., 4 (2012) 40 (in Russian).

4. Zhou Ch.H. An overview on strategies towards clay-based designer catalysts for green and sustainable catalysis, Appl. Clay Sci., 53 (2011) 87.

5. Oranska O.I., Brichka S.Ya., Gornikov Yu.I., Brichka A.V. Solid-state reactions of aluminosilicate nanotubes with oxides $3 d$ metals $\mathrm{NiO}, \mathrm{CuO}$ and $\mathrm{ZnO}$, IV Int. Conf. "NANSYS-2013" (Nov. 19-22, 2013, Kyiv, Ukraine), Abstract 156.

6. Palomba M., Porcu R. Thermal behavior of some minerals, J. Therm. Anal., 34 (1988) 711.

7. Madejova J., Keckes J., Palkova H., Komadel P. Identification of components in smectite/kaolinite mixtures, Clay Minerals, 37 (2002) 377.

8. Ptacek P., Soukal F., Opravil T. et al. The kinetics of Al-Si spinel phase crystallization from calcined kaolin, J. Solid State Chem., 183 (2010) 2565.

9. Martisius T., Giraitis R. Influence of cooper oxide on mullite formation from kaolinite, J. Mater. Chem., 13 (2003) 121.

10. Oranska O.I. Phase transformation in composites based on fumed separated and mixed silica and alumina and cooper oxide, Mater. Sci. Nanostruc., 1 (2011) 16 (in Russian).

11. Martinez J.R., Ortega-Zarzosa G., DominguesEspinos O., Ruiz $F$. Low temperature devitrification of $\mathrm{Ag} / \mathrm{SiO}_{2}$ and $\mathrm{Ag}(\mathrm{CuO}) / \mathrm{SiO}_{2}$ composites, J. Non-cryst. Solids, 282 (2001) 317.

12. Hedvall J.A. Einführung in die Festkörperchemie Die Wissenschaft Einzeldarstellungen aus der Naturwissenschaft und der Technik Band, Vieweg. Braunschweig, 1952, $106 \mathrm{p}$.

13. Hauffe K. Reaktionen in und an Festen Stoffen, Berlin, Springer, 1955, $696 \mathrm{p}$.

14. Garner W.E. Chemistry of the Solid State, London, Butterworths, 1955, $309 \mathrm{p}$.

15. Colinas J.M.F., Areán C.O. Kinetics of solidstate spinel formation: effect of cation coordination preference, J. Solid State Chemistry, 109 (1994) 43.

Received 24.06.2014, accepted 17.09.2014 